\title{
Evaluating the effect of certain lures in two different forms and traps on attraction of the mediterranean fruit fly, ceratitis capitata (weid.).
}

\author{
A.W.Makkar and T.S.El-Abbassi \\ Plant Protection Research Institute , Agricultural Research Center ,Egypt
}

\begin{abstract}
Field tests were conducted to evaluate the efficiency of three trap types (McPhail, Jackson and Makkar \& El-Abbassi ( a new trap ) \} and three attractant materials (Agrinal, Buminal and Conserve) against the Mediterranean fruit fly, Ceratitis capitata (Weid.).The attractant materials were used in two forms ( liquid form and in a paste form). Trials were carried out in two different locations at Qualubia Governorate within the period from October $29^{\text {th }}$ till December $25^{\text {th }} 2013$. First location ( Kafr Shokr district ) was cultivated with a mixture of some varieties of citrus trees, while the second location (El-Kanater district) was planted with navel orange. Data revealed that McPhail trap was superior among all tested traps based on potency and attraction of med flies ( specially females). On the other hand, the attractant material Agrinal was superior among other tested materials on basis of potency and attraction of adult flies. Moreover, the best combination between trap type and attractant material in attracting and capturing med fly adults was recorded when McPhail traps were loaded with Agrinal . Finally, results showed that number of attracted non-target organisms for all tested attractant materials were much higher in traps loaded with the attractant in a Iiquid form when compared with their corresponding in the paste form. Also , a bad smell ,rot and fungi growth were observed and recorded in McPhail traps loaded with the tested materials within few days post loading. Usage of the attractant material in a form of paste has some advantages based on : easy to use, no attraction of non-target organisims and avoidance of contamination with fungi and emission of bad smell. However more investigation should be conducted to increase its performance.
\end{abstract}

Key words: lures - trapes - mediterranean fruit fly -evaluation

\section{Introduction}

The mediterranean fruit fly, Ceratitis capitata (Wiedemann) is considered one of the most serious economic pests of fruits and vegetables. It attacks many fruit species and some vegetable crops such as tomatoes, peppers and egg-plant (El-Minshawy et al., 1999; Hashem et al. 2004 ; and Ghanim, 2009). Females are the main target for control because they damage fruits and are the dominant factor for multiplication. Female-attractive baits are therefore needed in any applicative system against these pests for both monitoring and direct control. Many researchers evaluated different compounds for attracting adults of medfly ( Hanafy et al 2001,Moustafa \&Ghanim 2008 , El-Gendy 2012 Saafan 2000\&2005 and Amin \& El-Metwally,2012 ). Synthetic food attractants for detection and delimitation of Ceratitis capitata and Anastrepha spp. (Caribbean/ Mexican fruit fly) have recently been developed, field tested and are currently being utilized in State and Federal survey programs (Heath et al., 1997, and Thomas et al., 2001 ). These attractant baits replace the aqueous slurry of torula yeast, which have long been the industry standard for tephritid fruit fly surveillance programs using food type baits (Burditt, 1982 and Cunningham, 1989). However, the protein-based liquids are attractive to a broad range of non-target insects, but this is less of a problem with the newer synthetic lures (Heath et al., 1995 and Katsoyannos et al., 1999). The objective of the current study was to provide fruit fly control program managers, with an easily handled, less costly, and equally (or more) effective bait dispenser system for use in detection programs against this pest.

\section{Material and Methods}

Experimental location: The present experiment was carried out in two different locations :

First location: was at Kafr Shokr District, Qaliubia governorate. The selected area was about 8 feddans planted with different citrus varieties (Valencia and navel oranges). Evaluation of tested trap types and tested materials started from date of hanging in October $29^{\text {th }}$ till November $14^{\text {th }} 2013$.

Second location: was at El-Kanater district , Qualiubia governorate, where about 8 feddans were cultivated with navel orange. Evaluation of tested trap types and materials started from date of hanging in November $14^{\text {th }}$ till December $25^{\text {th }} 2013$ and divided into two periods ( $A$ and $B$ ) :

A- From November $14^{\text {th }}$ till December $4^{\text {th }} 2013$, evaluation extended for three weeks .

B- From December $4^{\text {th }}$ till ${ }_{\text {December }} 25^{\text {th }} 2013$, evaluation extended for three weeks. 
Description of the experimental plot :

Each area was divided into three blocks, each of 2.5 feddans , about 1/4 feddan was left between every two blocks. Three blocks ( 3 traptypes $\times 3$ tested materials in each) were prepared for each experiment ( period) and distributed in a complete randomized block design .All traps were arranged uniformly and hanged at a height of $140-170 \mathrm{~cm}$ on the southern external branches of trees .

Trap types: Three trap types were used to catch med fly as illustrated in Fig(1) :

1- Glass McPhail traps (standard liquid trap) .

2- Jackson trap (sticky delta trap)

3- New Plastic (Makkar \& El-Abbassi ) trap

The latter trap consists of a yellow colored plastic bucket $13 \mathrm{~cm}$ height, the upper opening is $12 \mathrm{~cm}$ in diameter while the bottom diameter is $10 \mathrm{~cm}$. At the center of the bucket wall there are four evenly distributed holes. The outer diameter of each hole is $1.5, \mathrm{~cm}$, while the inner diameter is $0.6 \mathrm{~cm}$. The lid of trap is transparent

Tested attractant materials :

1- Agrinal

2- Buminal

3- Conserve

Treatments and preparing traps for use :

1- Glass McPhail traps were used by putting about $150 \mathrm{ml}$ of each attractant per trap at $5 \%$ concentration. 2- Jackson and Makkar\& ElAbbassi traps were prepared by using a paste consisted from the three attractant materials. The paste is composed from $15 \mathrm{~g}$ flour $+12 \mathrm{~g}$ starch + $4 \mathrm{~cm}^{3}$ paraffin oil + glycerin + the same concentrations of each test attractant material. Cloth muslin bags were used for covering the paste, and then placed in small cylindrical plastic containers opened at their two terminal ends. New sticky inserts were installed weekly in each Jackson trap.

At the end of each test period, the attractant solution in McPail traps was replaced by a solution of same concentration. At the end of first period, pastes were injected with $1 \mathrm{~cm}^{3}$ of the attractant materials, while at the end of second period, pastes were injected with $1 / 2 \mathrm{~cm}^{3}$ from the attractant materials . In all cases, captured med fly adults were collected in plastic cups, inspected twice per week in laboratory. Number of captured males and/or females was counted, recorded and values of captured flies per trap per day (CTD) were calculated.Statistical analysis was fulfilled by using a complete factorial experiment ( 3 traps $\times 3$ materials $\times 3$ blocks $)$.

\section{Results}

Data illustrated in tables 1, 2 and 3 represent the mean numbers of CTD values for med fly adults captured inside three trap types, three test materials and at three test blocks as well as the interaction between traps and tested materials throughout three weeks during the 3 experiments. In first experimental location at Kafr Shokr, Qualiubia governorate, the highest mean number of captured med fly adults ( 8.11) was recorded at $1^{\text {st }}$ week in McPhail trap, while the lowest mean number ( 0.22$)$ was recorded in the same trap at the $3^{\text {rd }}$ week (table, 1). Non significant difference in captivity of flies were noticed among the three tested traps. Computed (F) values were $2.05,2.44$ and 0.98 , respectively. In all cases, the efficiency of the three tested traps decreased by lapse of time. However, decline rates varied among tested traps. Decline rates for Makkar $\&$ El-Abbassi trap in $2^{\text {nd }}$ and $3^{\text {rd }}$ weeks in comparison with $1^{\text {st }}$ week were 46.1 and $83.5 \%$, respectively; while these values were $29.3 \& 79.4 \%$ in case of Jackson trap and $46.6 \& 97.3 \%$ in case of McPhail trap. This means that traps could be arranged according to their potency in attraction by lapse of time in a descending order as follows: Jackson trap $>$ Makkar \& El-Abbassi traps > McPhail trap .

Data represented in table (1) illustrate also values of cumulated mean numbers of CTD within the three weeks trial. These values were $0.27,0.42$ and 0.73 in cases of Makkar \& El-Abbassi trap, Jackson trap and McPhail trap, respectively. There was non significant difference in total mean number of captured flies among all tested trap types where the computed (F) value was 2.2 .

Comparative attractiveness of med fly adults by different attractive materials is also shown in table(1). The highest mean number of captured med flies throughout the three weeks of trial was recorded in both cases of Agrinal and Buminal (5.67) at first week, while the lowest value was 0.33 in cases of both Buminal and Conserve at the third week. No significant differences among tested materials were observed throughout the three weeks trail, where the computed (F) values were $0.49,1.39$ and 0.82 , respectively .Cumulated mean number of med flies captured per trap per day ( CTD ) were 0.56, o.57 and 0.31 in case of Agrinal, Buminal and Conserve, respectively. There was non significant difference in total mean number of attracted flies at the end of three weeks trial among all tested materials where the computed ( $\mathrm{F}$ ) value was 0.84 .

Data in table (1) revealed also that the efficiency of the three tested materials and the three trap types gave similar results within the three blocks in each week since no significant difference was found among the three blocks throughout the three weeks, where the computed $(\mathrm{F})$ values were $0.99,1.53$ and 0.82 , respectively. Meanwhile, the interaction between trap type and tested materials showed non significant difference in the three weeks, where the computed (F) values were 0.39, 2.03 and 0.51, respectively. 
Table 1. Mean numbers and CTD values of medfly adults in three trap types,three test materials and in three blocks at the first experimental location ,Kafr Shokr - Qalubia Governorate

\begin{tabular}{|c|c|c|c|c|c|c|c|c|}
\hline \multirow[b]{2}{*}{ Experiment 1} & \multicolumn{2}{|l|}{ Week 1} & \multicolumn{2}{|l|}{ Week 2} & \multicolumn{2}{|l|}{ Week 3} & \multicolumn{2}{|l|}{ Total } \\
\hline & $\begin{array}{l}\text { Mean } \\
\pm \mathrm{SE}\end{array}$ & CTD & $\begin{array}{l}\text { Mean } \\
\pm \mathrm{SE}\end{array}$ & CTD & $\begin{array}{l}\text { Mean } \\
\pm \mathrm{SE}\end{array}$ & CTD & Mean \pm SE & CTD \\
\hline \multicolumn{9}{|l|}{ Trap type } \\
\hline Makkar \& El-Abbassi & $2.67 \pm 0.78$ & 0.38 & $1.44 \pm 0.34$ & 0.21 & $0.44 \pm 0.14$ & 0.15 & $4.55 \pm 1.04$ & 0.27 \\
\hline Jackson & $3.78 \pm 0.73$ & 0.54 & $2.67 \pm 0.39$ & 0.38 & $0.78 \pm 0.05$ & 0.26 & $7.22 \pm 1.14$ & 0.42 \\
\hline McPhail & $8.11 \pm 0.05$ & 1.16 & $4.33 \pm 0.78$ & 0.59 & $0.22 \pm 0.10$ & 0.07 & $12.44 \pm 0.76$ & 0.73 \\
\hline Computed (F) & 2.05 & & 2.44 & & 0.98 & & 2.20 & \\
\hline \multicolumn{9}{|l|}{ Test Material: } \\
\hline Agrinal & $5.67 \pm 0.81$ & 0.81 & $2.89 \pm 0.19$ & 0.41 & $0.78 \pm 0.14$ & 0.26 & $9.33 \pm 0.98$ & 0.56 \\
\hline Buminal & $5.67 \pm 0.51$ & 0.81 & $3.67 \pm 0.48$ & 0.52 & $0.33 \pm 0.09$ & 0.11 & $9.67 \pm 0.89$ & 0.57 \\
\hline Conserve & $3.22 \pm 0.74$ & 0.46 & $1.67 \pm 0.46$ & 0.24 & $0.33 \pm 0.16$ & 0.11 & $5.22 \pm 0.94$ & 0.31 \\
\hline Computed (F) & 0.49 & & 1.39 & & 0.82 & & 0.84 & \\
\hline \multicolumn{9}{|l|}{ Replicates : } \\
\hline & $2.89 \pm 0.38$ & 0.41 & $2.89 \pm 0.19$ & 0.41 & $0.33 \pm 0.09$ & 0.11 & $4.89 \pm 0.84$ & 0.29 \\
\hline Block 1 & $4.78 \pm 0.77$ & 0.68 & $3.67 \pm 0.48$ & 0.52 & $0.78 \pm 0.19$ & 0.26 & $9.33 \pm 0.98$ & 0.55 \\
\hline $\begin{array}{l}\text { Block } 2 \\
\text { Block } 3\end{array}$ & $6.89 \pm 0.52$ & 0.98 & $1.67 \pm 0.46$ & 0.24 & $0.33 \pm 0.09$ & 0.11 & $10.0 \pm 0.79$ & 0.59 \\
\hline Computed (F) & 0.99 & & 1.53 & & 0.82 & & 1.06 & \\
\hline Interaction: & & & & & & & & \\
\hline Traps $\times$ materials & & & & & & & & \\
\hline Computed (F) & 0.39 & & 2.03 & & 0.51 & & 0.50 & \\
\hline $\begin{array}{l}\text { Tabulated (F) } \\
\text { At level } 5 \% \\
\text { df } 2,16\end{array}$ & \multicolumn{8}{|c|}{$\begin{array}{l}3.63 \\
\text { (for trap type, materials ,blocks) }\end{array}$} \\
\hline $\begin{array}{l}\text { Tabulated (F) } \\
\text { At level } 5 \% \\
\text { df } 4,16\end{array}$ & \multicolumn{8}{|c|}{$\begin{array}{l}3.01 \\
\text { ( for Interaction ) }\end{array}$} \\
\hline
\end{tabular}

Data represented in table (2) illustrate the results obtained from the second location, site (A) conducted at El-Kanater, Qualiubia governorate. In general, the obtained results were almost similar to those found in the first experiment carried out in Kafr Shokr, where the highest mean number of med fly adults captured (7.56) was recorded at the first week of trial in McPhail trap, and the lowest mean number (0.67) was recorded in the third week in Jackson trap. Non significant difference was found among the three tested trap types throughout the three weeks of the trial, where computed $(\mathrm{F})$ values were $2.92,0.16$ and 2.54, respectively. Cumulated mean values of CTD throughout the three weeks were 0.51. 0.46 and 0.8 in cases of Makkar \& El-Abbassi trap , Jackson trap and McPhail trap, respectively. Once more, non significant differences was found since the computed (F) value was 1.59 . Potency of tested trap types varied, attraction of Makkar \& El-Abbassi and Jackson traps increased in the second week by 44 \& $13 \%$ in relation to the first week, respectively, while in case of McPhail trap, the attraction of med flies decreased by $20.6 \%$. In the third week, efficiency of all tested traps tremendously decreased in comparison with second week. Percentages of decrement were 71.3, 86.0 and 44.5\% for Makkar \& El-Abbassi, Jackson and McPhail traps, respectively

As for the tested materials, Buminal gave the highest value of mean number of captured med fly adults (7.56) in the first week followed by Agrinal (6.11), these values were significantly higher than in case of Conserve (1.83) where the computed (F) value was 5.95 and L.S.D. $=3.62$. However, the least value (1.0) was recorded in the third week in traps loaded with Buminal. In $2^{\text {nd }}$ and $3^{\text {rd }}$ weeks, non significant difference was noticed among all tested materials. Data showed also that there were non significant differences in mean CTD values throughout the three weeks trial among all tested materials. Values of CTD were 0.77, 0.66 and 0.35 for Agrinal, Buminal and Conserve, respectively .

Data in table (2) indicated that the three tested materials as well as the three trap types gave similar results among the three blocks. Computed $(\mathrm{F})$ values were $1.58,0.54$ and 1.13, respectively. Meanwhile, the interaction between trap types and tested materials was also non insignificant in the three weeks where the computed $(\mathrm{F})$ values were 2.55 , 1.89 and 1.13 , respectively . 
Table 2. Mean numbers and CTD values of medfly adults in three trap types ,three test materials and in three blocks at the second experimental location site (A), El-kanater-Qalubia Governorate

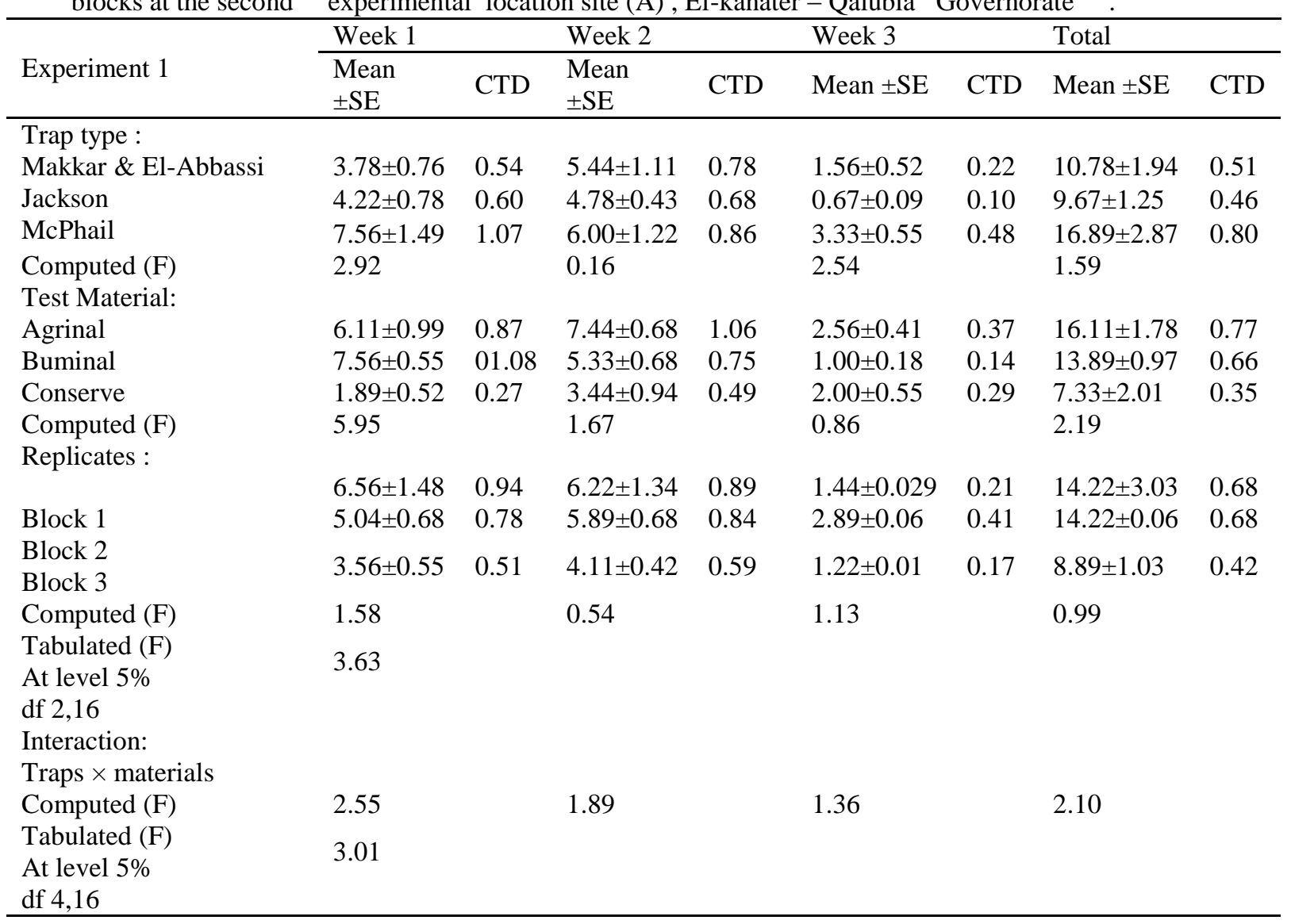

Data illustrated in table (3) differed from those obtained from experiments $1 \& 2$. The highest mean number of captured med fly adults (5.0) was noticed with McPhail trap ( liquid material) at the $1^{\text {st }}$ week of trial, while the lowest value was recorded at the $2^{\text {nd }}$ week $(0.11)$ in both cases of Makkar \& ElAbbassi and Jackson traps, where the attractant material was in a paste form. Significant differences among the three tested traps were calculated, where computed $(\mathrm{F})$ values were $4.71,5.76$ and 8.75 while L.S.D. values were $2.81,1.12$ and 1.43 , respectively. The cumulated mean number of med flies captured per trap per day (CTD) throughout three weeks were $0.22,0.41$ and 1.37 in cases of Makkar \& El-Abbassi traps, Jackson traps and McPhail traps, respectively. with nonsignificant difference in total mean number of captured flies among different trap types, where the computed $(\mathrm{F})$ value was 16.55 and L.S.D. $=3.16$. The highest mean number of captured med fly adults throughout three weeks was 3.44 in case of Conserve in the $1^{\text {st }}$ week, while the lowest value was in case of Buminal $(0.22)$ in the $2^{\text {nd }}$ week. Also nonsignificant difference among tested materials was found throughout the three weeks trial. The computed (F) values were $0.38,0.91$ and 1.16 , respectively. Cumulated mean values of CTD were $0.22,0.16$ and 0.28 in cases of Agrinal, Buminal and Conserve, respectively. with nonsignificant difference in total mean number between tested materials, where the computed $(\mathrm{F})$ value was 1.38 .

The efficiency of the three tested materials and the three trap types showed similar results among the three blocks every week. Therefore, there was

nonsignificant difference among the three blocks throughout the three week trial. The computed (F) values were $0.88,0.21$ and 0.94 , respectively . Results obtained from this experiment were similar to those obtained in experiments $1 \& 2$, where the interaction between trap types and tested materials had nonsignificant differences in the three weeks. The computed $(\mathrm{F})$ values were $1.24,0.56$ and 1.69 , respectively.

Data shown in table (4) illustrate cumulated mean numbers of med flies (males and/or females) captured inside the three tested trap types and/or materials throughout the three conducted experiments. In all cases, both sexes were attracted, however females were highly attracted than males. Sex ratio (male: female) ranged between 1: $2.7-1$ : 15. McPhail trap captured highest number of med fly females in the three experiments, $(15.67,11.67$ and 7.33 adults respectively). Jackson trap ranked the $2^{\text {nd }}$ where mean number of captured females were 8.22 , 6.33 and 2.67 in $1^{\text {st }}, 2^{\text {nd }}$ and $3^{\text {rd }}$ experiments , respectively. Makkar \& El-Abbassi traps were the least attractive for med fly females where mean 
number of attracted females were $7.89,3.44$ and 1.33 , respectively. No obvious trend on attracting med fly males in relation to trap type was observed. However, the highest mean number of attracted males in traps was found in case of Makkar \& ElAbbassi trap in the $1^{\text {st }}$ week (2.69) followed by McPhail trap in the $3^{\text {rd }}$ week (2.22). Mean number of captured med fly females was affected by the attractive material. Agrinal and Buminal were more attractive to females than Conserve. Mean numbers of attracted females in the three experiments were 14.6, 8.43 and 4.22 in case of Agrinal , $12.89,8.67$ and 3.0 in case of Buminal , while in case of Conserve those were 4.22, 4.33 and 4.1 , respectively. Also, no obvious trend on med fly male attraction was observed .Sex- ratios (male: female) in traps loaded with different attractant materials were higher in case of Agrinal \& Buminal in comparison with Conserve. Sex-ratio ranged between 1: 6.3 - 1: 12.9 in cases of Agrinal and Buminal, while it ranged between 1:2.5 - 1: 7.7 in case of Conserve.

Data obtained from these three experiments could be summarized as follows:

1- Effect of tested traps:

A- Potency of traps in attracting med fly adults by lapse of time could be arranged in a descending order as follows:

McPhail Trap > Makkar \& El-Abbassi trap > Jackson trap

B- Attraction of traps to med fly adults could be arranged as follows:

McPhail trap > Jackson trap > Makkar \& El-Abbassi

C- Effect on sex ratio (Females: males)

McPhail trap $>$ Jackson trap $>$ Makkar \& El-Abbassi

2-Tested material:

A- Potency in attraction of med fly adults

Agrinal $>$ Conserve $>$ Buminal

B- Attraction to med fly adults

Agrinal > Buminal > Conserve

C- Sex ratio (Females: males)

Buminal > Agrinal > Conserve

It was noticed that McPhail trap was superior among all tested traps based on potency; attraction of med flies especially females. As for tested materials, Agrinal was superior based on potency and attraction of flies. Therefore, and according to the obtained data, it could be concluded that the best combination between trap type and attractive material for med flies is McPhail trap + Agrinal

It was noticed that traps loaded with different attractant materials in either a liquid or a paste form have attracted other flies rather than med fly (trash flies) as well as some moths and spiders. Total numbers of non-target organisms attracted inside traps varied according to the attractant material. In general, numbers of attracted non-target organisms for all tested attractant materials were much higher in traps loaded with the attractants in liquid form when compared with their corresponding in traps mounted in the paste form. Moreover, a bad smell, rot and fungi were observed and recorded in some McPhail traps loaded with the tested materials

Data illustrated in table (5) showed that Agrinal attracted the highest number of non-target organisms followed by Conserve and Buminal. As for trap type, Makkar \& El-Abbassi trap attracted the least number of non-target organisms which is considered an advantage for this trap. Moreover, no rot or fungal growth were observed in case of either Makkar \& El-Abbassi trap or Jackson trap.

\section{Discussion}

The present investigation showed that in all cases both sexes of medfly were attracted, however females were mor attracted than males. Similar results were obtained by Steyskal (1977), Saafan (2005) and Ghanim (2009) who mentioned that MFF was attracted to different food attractant preparations. The present study showed that the efficiency of tested traps and/or attractive materials against med fly adults decreased by lapse of time however decline rate varied among tested traps or materials , while Moustafa and Ghanim (2008) and Ghanim (2009) mentioned that the efficiency of some ammonium compounds against MFF were not affected by time. Also Navarro-Llopis et al. ( 2008) found significant differences among different types of traps and dispensers in attractiveness of C.capitata . In this study, it was found that McPhail trap captured the highest number of med fly females while Makkar \& El-Abbassi trap was the least attractive for females, but the highest attractive to males. El-Gendy (2012) when tested the response of C.capitata to different attractant materials indicated that the highest attractive material was Buminal, while Moustafa (2009) stated that Buminal was more attractive than Agrinal to $C$. Capitata .Fresh Buminal was superiorly attractive. In this study, it was found that Agrinal and Buminal were more attractive to females than Conserve and no obvious trend on med fly male attraction was observed . Saafan (2005), Afia (2007) and Moustafa and Ghanim (2008) mentioned that females of MFF were more attracted to food attractants than males.

This study is considered the first attempt to use attractant materials for med flies when prepared in a paste form . Data revealed that using attractive materials in a paste form was promising because those are easier for use \& inspection, less environmental contaminant, less attraction of nontarget organisms and absence of rots or fungal growth inside traps. However more investigation should be conducted to improve its performance 
Table 3. Mean numbers and CTD values of medfly adults in three trap types, three test materials and in three blocks at the second experimental location site (B) El-Kanater-Qalubia Governorate

\begin{tabular}{|c|c|c|c|c|c|c|c|c|}
\hline \multirow[t]{2}{*}{ Experiment 1} & \multicolumn{2}{|l|}{ Week 1} & \multicolumn{2}{|l|}{ Week 2} & \multicolumn{2}{|l|}{ Week 3} & \multicolumn{2}{|l|}{ Total } \\
\hline & Mean \pm SE & CTD & Mean \pm SE & CTD & Mean \pm SE & CTD & Mean \pm SE & CTD \\
\hline Trap type : & & & & & & & & \\
\hline Makkar \& El-Abbassi & $1.00 \pm 0.24$ & 0.14 & $0.11 \pm 0.05$ & 0.02 & $0.44 \pm 0.05$ & 0.06 & $1.56 \pm 0.29$ & 0.22 \\
\hline Jackson & $2.33 \pm 0.33$ & 0.33 & $0.11 \pm 0.05$ & 0.02 & $0.44 \pm 0.10$ & 0.06 & $2.89 \pm 0.34$ & 0.41 \\
\hline McPhail & $5.00 \pm 0.63$ & 10.71 & $1.67 \pm 0.24$ & 0.24 & $2.89 \pm 0.47$ & 0.41 & $9.56 \pm 1.06$ & 1.37 \\
\hline Computed (F) & 4.71 & & 5,76 & & 8.75 & & 16.55 & \\
\hline Tabulated (F) & & & & & & & & \\
\hline $\begin{array}{l}\text { At level } 5 \% \\
\text { df } 2,16\end{array}$ & 3.63 & & & & & & & \\
\hline L.S.D. & 2.81 & & 1.12 & & 1.43 & & 3.16 & \\
\hline Test Material: & & & & & & & & \\
\hline Agrinal & $2.44 \pm 0.45$ & 0.35 & $0.89 \pm 0.21$ & 0.13 & $1.56 \pm 0.34$ & 0.22 & $4.89 \pm 0.69$ & 0.22 \\
\hline Buminal & $2.44 \pm 0.19$ & 0.35 & $0.22 \pm 0.10$ & 0.03 & $0.67 \pm 0.16$ & 0.10 & $3.33 \pm 0.36$ & 0.16 \\
\hline Conserve & $3.44 \pm 0.84$ & 0.49 & $0.78 \pm 0.14$ & 0.11 & $1.56 \pm 0.14$ & 0.22 & $5.78 \pm 0.62$ & 0.28 \\
\hline Computed (F) & 0.38 & & 0.91 & & 1.16 & & 1.38 & \\
\hline Replicates: & & & & & & & & \\
\hline & $2.44 \pm 0.45$ & 0.35 & $0.67 \pm 0.18$ & 0.10 & $1.11 \pm 0.23$ & 0.16 & $4.22 \pm 0.69$ & 0.20 \\
\hline Block 1 & $3.78 \pm 0.77$ & 0.54 & $0.78 \pm 0.14$ & 0.11 & $1.78 \pm 0.29$ & 0.25 & $6.33 \pm 0.51$ & 0.30 \\
\hline $\begin{array}{l}\text { Block } 2 \\
\text { Block } 3\end{array}$ & $2.11 \pm 0.23$ & 0.30 & $0.44 \pm 0.21$ & 0.06 & $0.89 \pm 0.19$ & 0.13 & $3.44 \pm 0.41$ & 0.16 \\
\hline Computed (F) & 0.88 & & 0.21 & & 0.94 & & 2.01 & \\
\hline Interaction: & & & & & & & & \\
\hline Traps $\times$ materials & & & & & & & & \\
\hline Computed (F) & 1.24 & & 0.56 & & 1.69 & & 1.99 & \\
\hline $\begin{array}{l}\text { Tabulated (F) } \\
\text { At level } 5 \% \\
\text { df } 4,16\end{array}$ & 3.01 & & & & & & & \\
\hline
\end{tabular}

Table 5. Total numbers of non-target organisms attracted into traps loaded with different attractant materials

\begin{tabular}{lllllll}
\hline \multirow{2}{*}{ Trap type } & Agrinal & \multicolumn{3}{c}{ Buminal } & \multicolumn{2}{c}{ Conserve } \\
\cline { 2 - 7 } & $\begin{array}{l}\text { Non- target } \\
\text { organisms }\end{array}$ & $\begin{array}{l}\text { Rots \& } \\
\text { fungi }\end{array}$ & $\begin{array}{l}\text { Non-target } \\
\text { organisms }\end{array}$ & Rot\& fungi & $\begin{array}{l}\text { Non-target } \\
\text { organisms }\end{array}$ & $\begin{array}{l}\text { Rot\& } \\
\text { fungi }\end{array}$ \\
\hline Makkar \& El-Abbassi & 18 & ------ & 2 & ------ & 3 & ----- \\
Jackson & 27 & ----- & 18 & ---- & 16 & ---- \\
McPhail & 143 & 11 & 82 & 10 & 104 & 11 \\
\hline
\end{tabular}

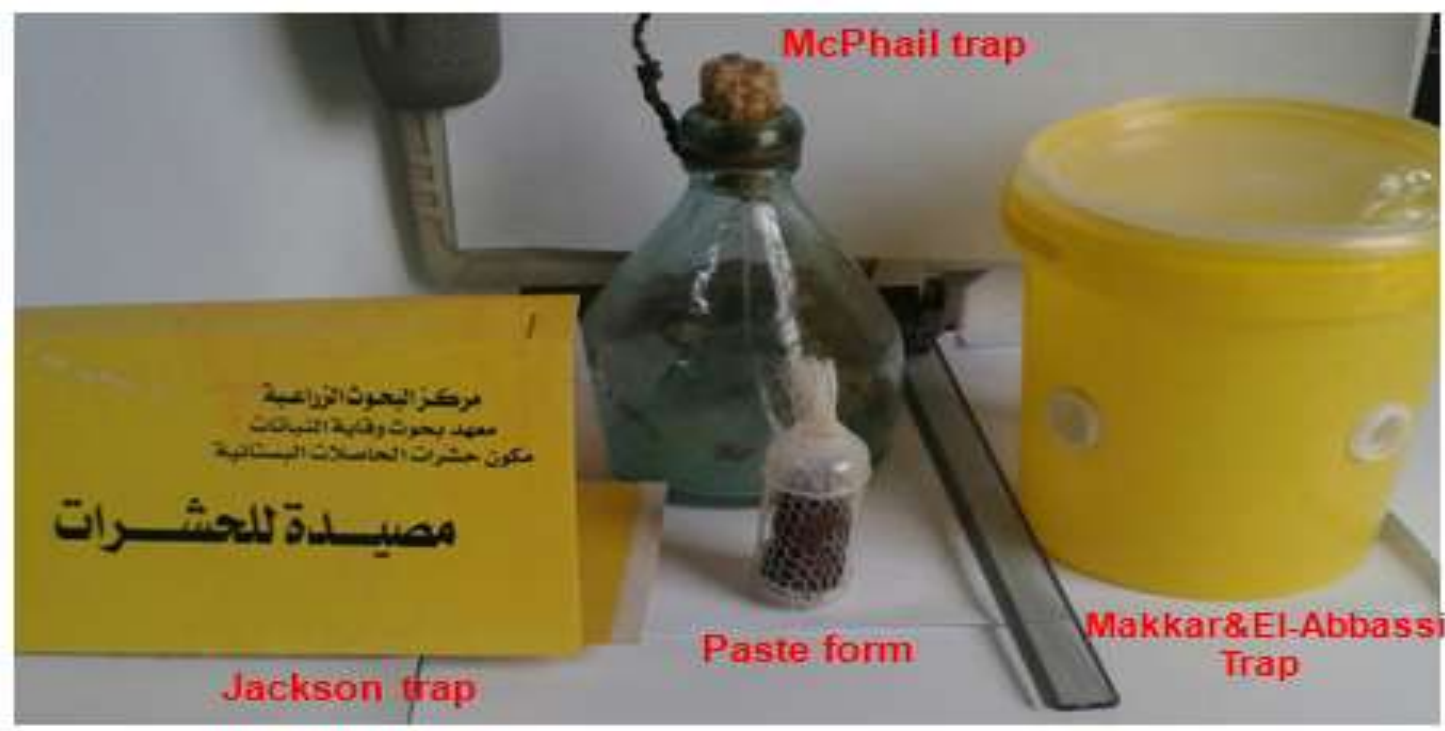

Fig. (1) Trap types used in the experiments 
Table 4. Mean numbers and percentages of captured males and females of Ceratitis capitata inside three trap types per each attractant material throughout three experiments

\begin{tabular}{|c|c|c|c|c|c|c|c|c|c|c|c|c|c|c|c|}
\hline \multicolumn{2}{|c|}{ Total } & \multirow{2}{*}{\multicolumn{6}{|c|}{ Test materials }} & \multirow{2}{*}{\multicolumn{2}{|c|}{$\begin{array}{l}\text { Wet traps } \\
9 \text { traps }\end{array}$}} & \multicolumn{4}{|c|}{ Dry mixture } & & \\
\hline & & & & & & & & & & 9 tra & + & aps & & & \\
\hline $27 \mathrm{tr}$ & & Con & & Bum & & Agrir & & $\mathrm{McP}$ & il trap & $\begin{array}{l}\text { Jack } \\
\text { trap }\end{array}$ & & $\begin{array}{l}\mathrm{Ma} \\
\mathrm{El}-\mathrm{f} \\
\text { trap }\end{array}$ & $\begin{array}{l}\text { ar \& } \\
\text { bassi }\end{array}$ & & \\
\hline$\%$ & $\begin{array}{l}\text { Mean } \\
\pm \text { SD }\end{array}$ & $\%$ & $\begin{array}{l}\text { Mean } \\
\pm \text { SD }\end{array}$ & $\%$ & $\begin{array}{l}\text { Mean } \\
\pm \text { SD }\end{array}$ & $\%$ & $\begin{array}{l}\text { Mean } \\
\pm \text { SD }\end{array}$ & $\%$ & $\begin{array}{l}\text { Mean } \\
\pm \text { SD }\end{array}$ & $\%$ & $\begin{array}{l}\text { Mean } \\
\pm S E\end{array}$ & $\%$ & $\begin{array}{l}\text { Mean } \\
\pm \mathrm{SD}\end{array}$ & $\underset{d}{凶}$ & 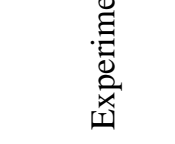 \\
\hline 1 & $5.56 \pm 0.4$ & 1 & $3.11 \pm 0.92$ & 1 & $1.00 \pm 0.31$ & 1 & $1.44 \pm 0.60$ & 1 & $1.22 \pm 0.37$ & 1 & $1-44 \pm 0.32$ & 1 & $2.69 \pm 0.9$ & male & $\frac{\text { Experiment }}{1}$ \\
\hline 5.7 & $31.77 \pm 2.2$ & 1.4 & $4.22 \pm 1.10$ & 12.9 & $12.89 \pm 1.14$ & 10.2 & $14.67 \pm 1.3$ & 12.8 & $15.67 \pm 2.5$ & 5.7 & $8.22 \pm 1.57$ & 2.7 & $7.89 \pm 1.7$ & female & $\begin{array}{l}\text { Kafr Shokr } \\
\text { First } \\
\text { location } \\
\text { Experiment }\end{array}$ \\
\hline 1 & $2.77 \pm 0.05$ & 1 & $0.89 \pm 0.28$ & 1 & $1.00 \pm 0.32$ & 1 & $0.89 \pm 0.14$ & 1 & $0.78 \pm 0.14$ & 1 & $0.89 \pm 0.19$ & 1 & $1.11 \pm 0.05$ & male & $\underline{2}$ \\
\hline 7.7 & $21.4 \pm 1.98$ & 4.9 & $4.33 \pm 0.80$ & 8.7 & $8.67 \pm 0.57$ & 9.5 & $8.43 \pm 0.90$ & 15 & $11.67 \pm 0.8$ & 7.1 & $6.33 \pm 0.98$ & 3.1 & $3.44 \pm 1.08$ & female & $\begin{array}{l}\text { El-Kanater } \\
2^{\text {nd }} \text { location } \\
\text { (A) } \\
\text { Experiment }\end{array}$ \\
\hline 1 & $2.67 \pm 0.57$ & 1 & $1.67 \pm 0.27$ & 1 & $0.33 \pm 0.16$ & 1 & $0.66 \pm 0.16$ & 1 & $2.22 \pm 0.43$ & 1 & $0.22 \pm 0.05$ & 1 & $0.22 \pm 0.10$ & male & $\underline{3}$ \\
\hline 4.3 & $11.33 \pm 0.77$ & 2.5 & $4.10 \pm 0.37$ & 9 & $3.00 \pm 0.24$ & 6.3 & $4.22 \pm 0.60$ & 2.5 & $7.33 \pm 6.40$ & 12 & $2.67 \pm 0.40$ & 6 & $1.33 \pm 0.24$ & female & $\begin{array}{l}\bar{E} \text { l-Kanater } \\
2^{\text {nd }} \text { location } \\
\text { (B) }\end{array}$ \\
\hline
\end{tabular}




\section{References}

Afia, Y. E. (2007). Comparative studies on the biology and ecology of the two fruit flies, in Egypt Bactrocera zonata (Saunders) and Ceratitis capitata (Wiedemann). Ph. D. Thesis, Faculty of Agriculture, Cairo Univ., 301pp.

Amin A. A. and El-Metwally, M. M. (2012) .Field evaluation of some attractants for mediterranean and peach fruit flies in Egypt. Assiut J. of Agric. Sci. 42(5): 165-178.

Burditt, A.K. (1982). Anastrepha suspensa (Loew) (Diptera: Tephritidae), McPhail traps for survey and detection. Florida Entomol. 65: 367-373.

Cunningham, R.T. (1989). Population detection. In A.S. Robinson and G. Hoopers (eds.). World Crop Pests 3B. Fruit flies and their biology, natural enemies and control. Elsevier, Amsterdam, 169-173.

El-Gendy,I.R. (2012). Evaluating attractency of some protein derivatives for the Mediterranean fruit fly, Ceratitis capitata (Wiedmann) and the peach fruit fly, Bactrocera zonata (Saunders). International Journal of Agricultural Research, 7: 185-194

EL-Minshawy, A. M.; El-Eryan, M. A. and Awad, A. I. (1999). Biological and morphological studies on the guava fruit fly, Bactrocera zonata (Saunders)(Diptera: Tephritidae) found recently in Egypt. 8th Nat. Conf. Pests \& Dis. of Veg. \& Fruits in Ismailia, Egypt, 71-82.

Ghanim, N. M. (2009). Studies on the peach fruit fly, Bactrocera zonata (Saunders)(Tephritidae, Diptera). Ph. D. Thesis, Fac. Agric. Mansoura Univ.

Hanafy, A. H.; Awad, A. I. and Abo-Sheasha, M. (2001). Field evaluation of different compounds for attracting adults of peach fruit fly Bactrocera zonata (Saunders) and Mediterranean fruit fly, Ceratitis capitata (Wied.) in guava orchards. J. Agric. Sci. Mansoura Univ., 26 (7): 4537-4546.

Hashem, A. G.; El-Wakad, M. F. and Soliman, N. A. (2004). The fruit flies. Egyptian Agric. Ministry, The Agricultural Guidance Division. No., 859: 1-35.

Heath, R.R., N.D. Epsky, A. Guzman, B.D. Dueben, A. Manukian, and W.L. Meyer (1995). Development of a dry insect trap with food based synthetic attractant for the Mediterranean and Mexican fruit, flies (Diptera: Tephritidae). J. Econ. Entomol. 88: 1307-1315.

Heath, R.R., N.D. Epsky, B.D. Dueben, Jorge Rizzo, and Felipe Jeronimo (1997). Adding methylsubstituted ammonia derivatives to a food-based synthetic attractant on captured Mediterranean and Mexican fruit flies. J. Econ. Entomol, Vol. 90(6): 1-6.

Katsoyannos, B.I., R.R. Heath, N.T. Papadopoulos, N.D. Epsky, and J. Hendrichs. (1999). Field evaluation of Mediterranean fruit fly (Diptera: Tephritidae) female selective attractants for use in monitoring programs. J. Econ. Entomol. Vol. 92: 442-452.

Moustafa, S. A (2009) Response of the Mediterranean fruit fly, Ceratitis capitata (Wied.) and peach fruit fly, Bactrocera zonata(Saund.) to some food attractants. Egypt. Acad. J. biolog. Sci., 2 (2): 111-118

Moustafa, S. A. and Ghanim, N. M. (2008). Some ammonium compounds as olfactory stimulants for Mediterranean fruit fly, Ceratitis capitata Wiedemann (Diptera: Tephritidae). J. Agric. Sci. Mansoura Univ., 33 (12): 8965-8973.

Navarro-Llopis,V. ; Alfaro,F. ; Dominguez ,J. ; Sanchis ,J. And Primo,J.,(2008).Evaluation of traps and lures for mass trapping of Mediterranean fruit fly in Citrus Groves. J. Econ. Entomol. 101(1):126-131.

Saafan, M. H. (2000). Field evaluation of some attractants for attracting the adults of Mediterranean fruit fly, Ceratitis capitata (Wied.). Egypt. J. Agric. Res., 78 (1): 97-107.

Saafan, M. H. (2005). Field evaluation of some attractants for attracting the adults of Mediterranean fruit fly, Ceratitis capitata (Wiedemann) and peach fruit fly, Bactrocera zonata (Saunders) in citrus orchards. Egypt. J. Agric. Res.,83 (3): 1141-1156.

Steyskal, G. (1977). History and use of McPhail trap. Fla. Ent., 60 : 11-16.

Thomas, D.B., T.C. Holler, R.R Heath, E. J. Salinas, and A.L. Moses. (2001). Trap-lure combinations for surveillance of Anastrepha fruit flies (Diptera: Tephritidae). Florida Entomologist 84(3): 344-351 


\title{
تقييم تأثير بعض المواد الجاذبة في صورتين مختلفتين والمصائد على جذب ذبابة فاكهة البحر المتوسط
} \\ البحر المنتسط .أجريت التجارب بمنطقتين بمحافظة القليوبية خلا الفترة من 29 اكتوبر وحتى 25 ديسمبر 2013 2013. وكانت المنطقة الأولى \\ بمركز كفر شكر مزروعة بأصناف مختلفة من أشجار الموالح ، أما المنطقة الثانية فكانت بمركز القناطر مزروعة بأشجار البرتقال صنف أبو سرة.

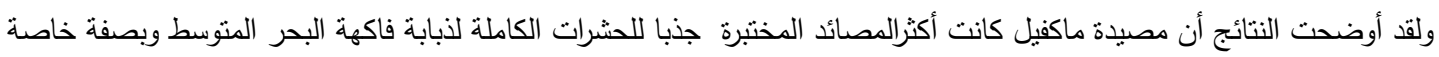 \\ الإناث مقدرة على أساس قوة الجذب وطول مدة الجذب ـ من جهة أخرى أظهرت مادة الأجرينال أنها أكثر المواد جذبا أيضا على أساس قوة \\ الجذب وطول مدة الجذب ـ كما أظهرت النتائج أيضا أن أفضل توافق بين نوع المصيدة والمادة الجاذبة نم تسجيله عندما استخدمت مصائد ماكفيل

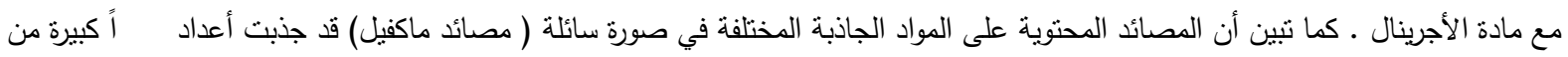 \\ حشرات وكائنات أخري بخلاف ذبابة الفاكهة كما صاحب ذللك إنبعاث روائح كربهة وظهور نموات فطرية بها ، في حين لم بلاحظ ذللك في

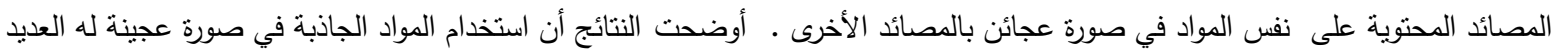

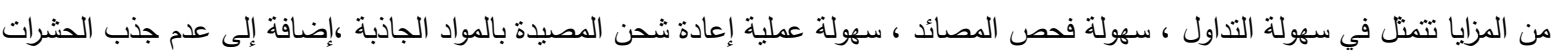

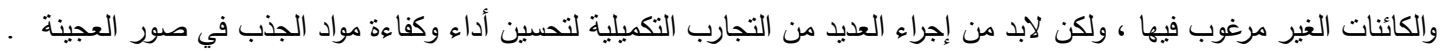

